SAINS TANAH - Journal of Soil Science and Agroclimatology

Journal homepage: http://jurnal.uns.ac.id/tanah

\title{
Mycorrhizae and a soil ameliorant on improving the characteristics of sandy soil
}

\author{
Aktavia Herawati ${ }^{1 *}$, Jauhari Syamsiyah ${ }^{1}$, Mujiyo ${ }^{1}$, Mapan Rochmadtulloh ${ }^{2}$, Afifah Afiana Susila ${ }^{2}$, Muhammad \\ Rizky Romadhon ${ }^{2}$
}

${ }^{1}$ Department of Soil Science, Faculty of Agriculture, Sebelas Maret University, Surakarta, Indonesia

${ }^{2}$ Undergraduate Program of Soil Science Dept., Faculty of Agriculture, Sebelas Maret University, Surakarta, Indonesia

\begin{tabular}{|c|c|}
\hline ARTICLE INFO & ABSTRACT \\
\hline $\begin{array}{l}\text { Keywords: } \\
\text { Cow dung } \\
\text { Biochar } \\
\text { Rock phosphate } \\
\text { SOC } \\
\text { Glomalin } \\
\text { Article history } \\
\text { Submitted: 2020-08-12 } \\
\text { Accepted: 2021-06-3 } \\
\text { Available online: 2021-06-30 } \\
\text { Published regularly: June 2021 } \\
\text { * Corresponding Author } \\
\text { Email address: } \\
\text { aktavia_h@staff.uns.ac.id }\end{array}$ & $\begin{array}{l}\text { Agricultural constraints on sandy soil are poor chemical characteristics and low biological } \\
\text { activity resulting in the soil becoming less productive to be planted. One of the efforts to } \\
\text { improve the quality of sandy soil is an application of mycorrhizae and a soil ameliorant. The } \\
\text { purpose of this study was to determine the effect of mycorrhizae and a soil ameliorant on } \\
\text { soil chemical characteristics and soil biological activity. The experiment was arranged using } \\
\text { a Complete Randomized Design with two factors. The first factor (1) was mycorrhizae dose, } \\
\text { without mycorrhizae (M0) and six spores of mycorrhizae/plant (M1), and the second factor } \\
\text { (2) was types of soil ameliorant, without ameliorant (SO), cow dung (S1), rock phosphate } \\
\text { (S2), biochar (S3), cow dung-rock phosphate (S4), cow dung-biochar (S5), and rock } \\
\text { phosphate-biochar (S6). The results indicated that combination of six spores } \\
\text { mycorrhizae/plant-cow dung } 60 \text { tons ha }{ }^{-1}-\text { biochar } 25 \text { tons ha }{ }^{-1} \text { (M1S5) increased soil } \\
\text { organic carbon (SOC) ( } 235 \% \text { ), available } \text { ( } 675 \%) \text {, cation exchange capacity (CEC) ( } 216 \%) \text {, } \\
\text { total glomalin (101\%), and easily extracted glomalin (69\%), decreased exchangeable } \\
\text { sodium percentage (66\%), and increased absolutely for root infection and spore density } \\
\text { than without mycorrhizae and a soil ameliorant (control). The lowest SOC, total glomalin } \\
\text { and easily extracted glomalin were found on non-mycorrhizae-rock phosphate, but } \\
\text { available P, CEC, root infection, spore density were found on the control. The application } \\
\text { of mycorrhizae, cow dung, and biochar improved the sandy soil characteristics. }\end{array}$ \\
\hline
\end{tabular}

How to Cite: Herawati, A., Syamsiyah, J., Mujiyo, Rochmatulloh, M., Susila, A. A., Romadhon, M. R. (2021). Mycorrhizae and a soil ameliorant on improving the characteristics of sandy soil [Research]. Sains Tanah Journal of Soil Science and Agroclimatology, 18(1): 73-80. https://dx.doi.org/10.20961/stjssa.v18i1.43697

\section{Introduction}

The decrease in agricultural land becomes a problem because it leads to a decrease in land productivity and food production, whereas demand for food keeps increasing. Thus, agricultural extensification is required and could be done by utilizing coastal sandy soil. This soil possesses poor chemical and biological quality and becomes the limiting factor for plant growth. Sandy soil has low organic matter content, total nitrogen, and cation exchange capacity (CEC) (Rahayu, Saidi, et al., 2019; Zulkoni et al., 2020), which will lead to low fertility, water retention, and macro and micronutrient content (Yost \& Hartemink, 2019). Its properties also do not provide support for microorganisms' life (Huang \& Hartemink, 2020).

There have been studies demonstrating that mycorrhizae and a soil ameliorant positively affect soil and plant growth.
The contribution of subsoil arbuscular mycorrhizae fungi was to enhance soil formation, reduction of nutrient leaching, access to deep nutrient and water pools in the suboptimal conditions that prevail in the topsoil, and improvement of the soil structure, leading to aggregate-protected organic matter, competition with saprotrophic bacteria and fungi, thus reducing decomposition rates, increased carbon input in subsoil via mycelial exudates and turnover and formation of highly stable mineral-associated organic matter fractions (Sosa-Hernández et al., 2019) and increasing the P availability in the desertification soils in the Karst area (Li et al., 2019). The mineral status of plants in potassium was enhanced by mycorrhizae treatment up to $0.53 \mathrm{mg} \mathrm{g}^{-1}$ dry weight for bean plants and $0.50 \mathrm{mg} \mathrm{g}^{-1}$ for wheat plants in Mediterranean semi-arid areas (Raklami et al., 2019). 
Research on soil ameliorants has been previously carried out. Application of cow dung in sandy soils increases soil cation base, moisture content, soil C-organic content (Han et al., 2016; Xie et al., 2015), and total chili production (Putra et al., 2020). The addition of biochar increased nutrient availability and water retention while also providing favorable habitats for symbiotic microorganisms such as mycorrhizae (Zhang et al., 2017). Kocsis et al. (2020) also reported that appropriate biochar doses are needed for the improvement of soil biological activities and increased yield of maize compared to the control. In addition, bacterial inoculation in biochar-based rock phosphate enhanced available $P$ in soil (de Amaral Leite et al., 2020). Mycorrhizae colonization was significantly decreased fertilizer input by $100 \mathrm{mg} \mathrm{P} \mathrm{kg}^{-1}$; and a combination of mycorrhizae fungi, biochar and $P$ fertilizer significantly increased shoot biomass in polluted soils (Xiao et al., 2020) and the growth of chili in sandy soil (Putra et al., 2020). Liu et al. (2020) reported that in cadmium (Cd)polluted soils, treatment with no biochar and $P$ input had a positive mycorrhizae response, but treatment with biochar or high-P input had a negative mycorrhizae response.

Various studies using mycorrhizae and soil ameliorants have been successfully carried out in various soils, but nothing is specific to sandy soils. The research on mycorrhizae and soil ameliorants in sandy soil is needed because the chances of success and novelty from this research are very high. This research aimed to determine the effect of mycorrhizae and a soil ameliorant on soil chemical characteristics and soil biological activity in sandy soil.

\section{Materials and Methods}

This experiment was conducted from May to September 2019 at the Screen House of the Faculty of Agriculture of Sebelas Maret University. The experiment was a polybag experiment with $10 \mathrm{~kg}$ of soil per polybag, arranged using complete a randomized design consisting of two factors. The first factor was the dosage of mycorrhizae, without mycorrhizae (M0) and with six spores mycorrhizae/plant (M1). The mycorrhizae used are an endomycorrhizal biofertilizer with 30 spores in 50 grams of zeolite carriers, which means that at 10 grams of zeolite carriers, there are six mycorrhizae spores. The determination of the dose of six mycorrhizae spores plants was based on a previous study by Syamsiyah et al. (2014), which demonstrated that the mycorrhizae dose of $5 \mathrm{~g} \mathrm{plant}^{-1}$ showed the best results in paddy rice. The second factor was a soil ameliorant, without an ameliorant (SO), cow dung 60 tons ha ${ }^{-1}$ (S1) (Prasetyo, 2014), rock phosphate $150 \mathrm{~kg} \mathrm{ha}^{-1}(\mathrm{~S} 2)$, biochar 25 tons ha ${ }^{-1}$ (S3) (Rahayu, Saidi, et al., 2019), cow dung 60 tons ha ${ }^{-1}+$ rock phosphate $150 \mathrm{~kg} \mathrm{ha}^{-1}$ (S4), cow dung 60 tons ha ${ }^{-1}+$ biochar 25 tons ha ${ }^{-1}$ (S5), and rock phosphate $150 \mathrm{~kg} \mathrm{ha}^{-1}+$ biochar 25 tons ha-1 (S6). Each unit of the experiment was repeated three times so that there were 42 total polybags experimental units.

The sandy soil used in this study was taken from Bantul Regency of Yogyakarta Province, Indonesia, characterized by neutral soil $\mathrm{pH} \mathrm{H}_{2} \mathrm{O}$ (1:2.5); very low total nitrogen, C-organic, and cation exchange capacity (CEC); low available $\mathrm{P}$ and $\mathrm{K}$ (Table 1). Application of mycorrhizae was carried out during the transplanting of chili seedlings. At harvesting (110 days after planting), tissue samples were taken by cutting the stem of the plant and leaving the roots planted in the soil. Then, the remaining roots were stressed for 7 days, after which the soil samples and root samples were taken for laboratory analysis.

Parameters of soil characteristics include $\mathrm{pH}$ of the soil using a potential metric method; available $\mathrm{P}$ was analyzed using the Olsen method; soil organic carbon (SOC) was analyzed using the Walkley and Black method; CEC, base saturation, and exchangeable sodium percentage (ESP) were analyzed using the Ammonium Acetate $\mathrm{pH} 7.0$ saturation method. The parameters of soil biological activity include mycorrhizae infection using the Tryphan blue staining method and spore density analyzed using the wet sieved method, and glomalin levels were analyzed using the glomalin extraction method. The data obtained were analyzed by using Analysis of Variance with a confidence level of 95\%; then, Tukey HSD was conducted with a confidence level of $95 \%$. To find the relationship between parameters, the Pearson correlation test was used.

\section{Results}

\subsection{Effect of mycorrhizae and soil ameliorants on soil chemical characteristics}

The combination of mycorrhizae and soil ameliorants has a significant effect on available $\mathrm{P}, \mathrm{SOC}, \mathrm{CEC}$, base saturation and ESP but not significant on the soil $\mathrm{pH}$ (Table 2). The range of $\mathrm{pH}$ in all treatments of mycorrhizae and ameliorant combinations was classified as neutral (7.33-7.51). Even without the application of mycorrhizae and soil ameliorants, soil $\mathrm{pH}$ in the control treatment (MOSO) and initial soil $\mathrm{pH}$ were classified as neutral. Application of mycorrhizae-rock phosphate $150 \mathrm{~kg} \mathrm{ha}^{-1}$ resulted in the highest of available $P$ (115.17 ppm) but was not significantly different from the application of mycorrhizae-cow dung and mycorrhizae-cow dung-biochar (Table 3). The treatment of mycorrhizae-rock phosphate presented the highest available $\mathrm{P}$ (115.17 ppm), which was 12.8 times higher than that of the control treatment (9.99 ppm). Application of mycorrhizae and types of soil ameliorant significantly affected SOC (Table 3 ).

Table 1. Initial sandy soil characteristics

\begin{tabular}{cccc}
\hline No & Characteristic (unit) & Method & Value \\
\hline 1. & $\mathrm{pH} \mathrm{H}_{2} \mathrm{O}$ & Potentiometric & 7.12 \\
2. & Soil organic C (\%) & Walkley and Black & 0.18 \\
3. & Total N (\%) & Kjeldahl & 0.015 \\
4. & Available P $(\mathrm{ppm})$ & Olsen & 7.34 \\
5. & Available K & Saturation of $\mathrm{NH}_{4} \mathrm{OAc} 1$ & 0.27 \\
6. & (me $/ 100 \mathrm{~g})$ & $\mathrm{N}$ & \\
7. & CEC $(\mathrm{cmol} / \mathrm{kg})$ & Saturation NH4OAc 1 N & 4.43 \\
\hline
\end{tabular}

Remark: ud = undefined 
Table 2. P-value from ANOVA test on soil chemical characteristic $(\alpha=0.05)$

\begin{tabular}{ccccccc}
\hline Parameter & $\mathrm{pH}$ & Available P & SOC & CEC & Base saturation & ESP \\
\hline Mycorrhizae (M) & $0.717^{\mathrm{ns}}$ & $<0.01^{* *}$ & $0.990^{\mathrm{ns}}$ & $<0.01^{* *}$ & $<0.01^{* *}$ & $0.284^{\mathrm{ns}}$ \\
Soil Ameliorant (S) & $0.984^{\mathrm{ns}}$ & $<0.01^{* *}$ & $<0.01^{* *}$ & $<0.01^{* *}$ & $<0.01^{* *}$ & $<0.01^{* *}$ \\
$\mathrm{M}^{*} \mathrm{~S}$ & $0.937^{\mathrm{ns}}$ & $<0.01^{* *}$ & $<0.01^{* *}$ & $<0.01^{* *}$ & $<0.01^{* *}$ & $<0.01^{* *}$ \\
\hline
\end{tabular}

Remarks: SOC= Soil Organic Carbon; CEC= Cation Exchangeable Capacity; ESP= Exchangeable Sodium Percentage; ns= no significant difference; ${ }^{* *}=$ highly significant difference

Table 3. Effect of mycorrhizae and soil ameliorant on soil chemical properties

\begin{tabular}{|c|c|c|c|c|c|c|c|}
\hline \multicolumn{2}{|c|}{ Treatment } & $\mathrm{pH}$ & Available P (ppm) & SOC (\%) & $\mathrm{CEC}\left(\mathrm{cmol} \mathrm{kg}^{-1}\right)$ & Base saturation (\%) & ESP (\%) \\
\hline \multirow{7}{*}{ MO } & So & $7.48 \pm 0.09$ & $9.99 \pm 0.28 c$ & $0.17 \pm 0.01 \mathrm{~d}$ & $4.57 \pm 0.34 d$ & $43.46 \pm 1.91 b c$ & $28.73 \pm 0.22 \mathrm{a}$ \\
\hline & S1 & $7.51 \pm 0.17$ & $30.01 \pm 3.50 \mathrm{bc}$ & $0.32 \pm 0.02 \mathrm{bcd}$ & $6.58 \pm 1.56 \mathrm{~cd}$ & $35.60 \pm 8.10 \mathrm{bcde}$ & $15.83 \pm 3.28 \mathrm{bcde}$ \\
\hline & S2 & $7.39 \pm 0.22$ & $25.25 \pm 2.38 b c$ & $0.11 \pm 0.12 \mathrm{~d}$ & $9.50 \pm 0.99 b c$ & $43.19 \pm 2.96 b c$ & $18.59 \pm 0.65$ bcde \\
\hline & S3 & $7.45 \pm 0.11$ & $29.28 \pm 6.03 \mathrm{bc}$ & $0.22 \pm 0.06 \mathrm{~cd}$ & $8.76 \pm 0.19 c$ & $30.21 \pm 1.89 \mathrm{cde}$ & $14.81 \pm 1.51 \mathrm{cde}$ \\
\hline & S4 & $7.44 \pm 0.24$ & $55.26 \pm 34.54 \mathrm{bc}$ & $0.45 \pm 0.01 b c$ & $6.74 \pm 0.74 \mathrm{~cd}$ & $81.79 \pm 9.43 a$ & $19.34 \pm 3.84 \mathrm{bcd}$ \\
\hline & S5 & $7.50 \pm 0.12$ & $23.53 \pm 3.37 \mathrm{bc}$ & $0.80 \pm 0.13 a$ & $8.19 \pm 0.59 \mathrm{~cd}$ & $42.53 \pm 3.04 b c$ & $14.55 \pm 1.88 \mathrm{cde}$ \\
\hline & S6 & $7.40 \pm 0.29$ & $18.12 \pm 5.23 c$ & $0.17 \pm 0.15 d$ & $9.58 \pm 0.34 b c$ & $34.82 \pm 2.45 \mathrm{cde}$ & $16.38 \pm 1.73 \mathrm{bcde}$ \\
\hline \multirow{7}{*}{ M1 } & SO & $7.55 \pm 0.23$ & $21.01 \pm 3.27 \mathrm{c}$ & $0.12 \pm 0.15 d$ & $7.31 \pm 0.32 \mathrm{~cd}$ & $35.88 \pm 0.44$ bcde & $21.70 \pm 0.70 \mathrm{abc}$ \\
\hline & S1 & $7.33 \pm 0.48$ & $77.47 \pm 34.16 \mathrm{ab}$ & $0.56 \pm 0.18 a b$ & $8.65 \pm 0.63 c$ & $40.73 \pm 3.96 \mathrm{bcd}$ & $13.62 \pm 1.80 \mathrm{cde}$ \\
\hline & S2 & $7.48 \pm 0.25$ & $115.17 \pm 45.70 \mathrm{a}$ & $0.07 \pm 0.02 \mathrm{~d}$ & $6.08 \pm 1.00 \mathrm{~cd}$ & $51.95 \pm 11.10 \mathrm{~b}$ & $24.16 \pm 7.02 a b$ \\
\hline & S3 & $7.41 \pm 0.37$ & $23.99 \pm 8.68 b c$ & $0.32 \pm 0.12 \mathrm{bcd}$ & $8.79 \pm 0.42 c$ & $29.16 \pm 2.48 \mathrm{cde}$ & $19.49 \pm 2.33 \mathrm{bcd}$ \\
\hline & S4 & $7.49 \pm 0.31$ & $27.33 \pm 3.93 b c$ & $0.27 \pm 0.01 \mathrm{~cd}$ & $12.99 \pm 1.92 \mathrm{ab}$ & $22.43 \pm 5.50 \mathrm{e}$ & $11.81 \pm 4.14 \mathrm{de}$ \\
\hline & S5 & $7.33 \pm 0.02$ & $77.45 \pm 13.93 \mathrm{ab}$ & $0.57 \pm 0.13 a b$ & $14.43 \pm 3.68 a$ & $24.95 \pm 5.90 \mathrm{de}$ & $9.80 \pm 2.11 \mathrm{e}$ \\
\hline & S6 & $7.39 \pm 0.09$ & $20.38 \pm 5.80 c$ & $0.33 \pm 0.10 \mathrm{bcd}$ & $8.82 \pm 1.20 c$ & $29.01 \pm 5.33 \mathrm{cde}$ & $20.44 \pm 4.00 \mathrm{abcd}$ \\
\hline
\end{tabular}

Remarks: The numbers after the \pm sign are standard deviation, the means followed by the same letters in the same column indicate no significant difference according to Tukey HSD $(\alpha=5 \%)$; SOC= Soil Organic Carbon CEC $=$ Cation Exchangeable Capacity; ESP= Exchangeable Sodium Percentage; M0= without mycorrhizae; M1= mycorrhizae 6 spores/plant; S0= without ameliorant; S1= cow dung 60 tons ha-1, S2= rock phosphate $150 \mathrm{~kg} \mathrm{ha}^{-1}$; S3= biochar 25 tons ha-1; S4= cow dung 60 tons ha-1 + rock phosphate $150 \mathrm{~kg} \mathrm{ha}^{-1} ; \mathrm{S} 5=$ cow dung 60 tons ha-1 + biochar 25 tons ha-1 ; $S 6=$ rock phosphate $150 \mathrm{~kg} \mathrm{ha}^{-1}+$ biochar 25 tons ha-1

The combination of cow dung-biochar without mycorrhizae (MOS5) had the highest of soil organic C $(0.8 \%)$, which increased up to 4.7 times compared to the control $(0.17 \%)$. Application of mycorrhizae-rock phosphate $150 \mathrm{~kg} \mathrm{ha}^{-1}$ was the lowest of soil organic C $(0.07 \%)$.

The combination of mycorrhizae and soil ameliorant significantly affected CEC (Table 3 ). The highest of CEC (14.43 $\mathrm{cmol} \mathrm{kg}^{-1}$ ) was found in the combination of mycorrhizae-cow dung 60 tons ha ${ }^{-1}$ with biochar 25 tons ha-1 (M1S5), increasing up to 3.16 times than that in the control $\left(4.57 \mathrm{cmol} \mathrm{kg}^{-1}\right)$. Interaction of mycorrhizae and soil ameliorants had a significant effect on base saturation. The highest base saturation was found on the treatment without mycorrhizaecow dung-rock phosphate (81.79\%) (MOS4) and was significantly different from that due to other treatments (Table 3). The combination of mycorrhizae-cow dung-rock phosphate contributed to increasing base saturation in the soil by 1.88 times compared to the control (43.46\%). The combination of mycorrhizae and soil ameliorants has a significant effect on decreasing the ESP value (Table 3). The lowest ESP was found on the combination of mycorrhizaecow dung-biochar (9.80\%), lower up to 2.99 times than that on the control (28.73\%). The highest ESP was found in the control.

\subsection{Effect of mycorrhizae and soil ameliorants on soil biological characteristics}

The application of mycorrhizae combined with soil ameliorants had a significant effect on root infection, spore density, easily extracted glomalin (EEG), and total glomalin (TG) in soil, as presented in Table 4. Application of mycorrhizae without soil ameliorants (M1S0) had the highest root infection (98.33\%), spore density (54 spores/100 grams of soil), and TG $\left(0.300 \mathrm{mg} \mathrm{g}^{-1}\right)$, but application of mycorrhizae-cow dung 60 tons ha ${ }^{-1}$ (M1S1) had the highest EEG (0.290 $\mathrm{mg} \mathrm{g}^{-1}$ ) (Table 5). Root infection on the only mycorrhizae was not significantly different with a combination of mycorrhizae-cow dung-rock phosphate (M1S4). On mycorrhizae treatment, application of biochar 25 tons $\mathrm{ha}^{-1}$ resulted in the lowest root infection $(70 \%)$ and spore density (20/100-gram soil). All types of soil ameliorants without mycorrhizae prevented root infection and spore density.

Application of mycorrhizae-cow dung 60 tons ha ${ }^{-1}$ (M1S1) was the best for EEG $\left(0.290 \mathrm{mg} \mathrm{g}^{-1}\right)$, and application of only rock phosphate $150 \mathrm{~kg} \mathrm{ha}^{-1}$ was the lowest of EEG $(0.038 \mathrm{mg}$ $\left.\mathrm{g}^{-1}\right)$. The application of only mycorrhizae (M1S0) and mycorrhizae-cow dung 60 ton ha ${ }^{-1}$ (M1S1) were the best on TG up to $0.300 \mathrm{mg} \mathrm{g}^{-1}$ but not significantly different with the application of mycorrhizae-cow dung (MOS1) $\left(0.299 \mathrm{mg} \mathrm{g}^{-1}\right)$ and mycorrhizae-rock phosphate $\left(0.298 \mathrm{mg} \mathrm{g}^{-1}\right)$ (Table 5). Application of only $150 \mathrm{~kg} \mathrm{ha}^{-1}$ of rock phosphate was the lowest of TG $\left(0.044 \mathrm{mg} \mathrm{g}^{-1}\right)$.

The available $P$ had a positive correlation with root infection $(r=0.364, P<0.05)$, spore density $(r=0.363, P<$ $0.05)$, TG $(r=0.318, P<0.05)$ but a negative correlation with EEG $(r=-0.411, P<0.01)$, as presented in Table 6 . Cation exchange capacity had a positive correlation with root 
infection $(r=0.378, P<0.05)$ and spore density $(r=0.307, P<$ 0.05). Root infection had a strong positive correlation with spore density $(r=0.946, P<0.01)$, TG $(r=0.485, P<0.01)$ and easily extracted glomalin $(r=0.378, P<0.05)$; spore density had a strong positive correlation with TG $(r=0.490, P<0.01)$; and TG had a strong positive correlation with EEG $(r=0.476$, $P<0.01)$.

\section{Discussion}

The interaction of mycorrhizae-cow dung-biochar (M1S5) significantly increased SOC $(0.57 \%)$, CEC $(14.43 \mathrm{cmol}$ $\left.\mathrm{kg}^{-1}\right)$, root infection (90\%), and spore density (44/100 grams of soil) and reduce the ESP value $(9.80 \%)$ in sandy soils (Table 3 and Table 5). Application of mycorrhizae-rock phosphate significantly increased $\mathrm{P}$ availability up to 115.17 ppm (Table 3). By contrast, the application of mycorrhizae-cow dung (M1S1) significantly increased EEG $\left(0.290 \mathrm{mg} \mathrm{g}^{-1}\right)$ and TG $0.300 \mathrm{mg} \mathrm{g}^{-1}$ (Table 5). In line with $\mathrm{Wu}$ et al. (2015), mycorrhizae significantly increased the production of $\mathrm{EE}-$ glomalin-related soil protein (GRSP), T-GRSP, and SOC, production of EE-GRSP and T-GRSP significantly positively correlated with SOC.

An increase of SOC increased CEC. SOC and CEC on mycorrhizae-cow dung-biochar increased by $235 \%$ and $216 \%$, respectively, compared to control. Ramos et al. (2018) reported that organic carbon influenced the sign and the magnitude of the net charge of the soils and contributed approximately 40 times more to the CEC than the clay fraction, the increase in CEC due to the increase of the organic carbon content. CEC was strongly linked to SOC, especially in the top mineral soil with the larger presence of organic matter (Solly et al., 2019). Minardi et al. (2020) reported that adding cow manure to the soil resulted in the highest soil organic matter in Alfisols, due to the decomposing organic matter from cow manure. Adding mycorrhizae-rock phosphate increased available phosphor. Sosa-Hernández et al. (2019) reported that $P$ uptake increased significantly with the addition of mycorrhizae through increased water-holding capacity, reduction of the risk of leaching, and intercept $P$ that has migrated down the soil profile and delivered $P$ to the plant. The role of mycorrhizae on $P$ availability through solubilization and mineralization reactions, and immobilization of $P$ into microbial biomass and/or formation of sparingly available forms of inorganic and organic soil $\mathrm{P}$, or increased root growth through either an extension of existing root systems (e.g., mycorrhizal associations) or hormonal stimulation of root growth, branching, or root hair development (Richardson \& Simpson, 2011). Mycorrhizae inoculants combination with rock phosphate can be used as a suitable biofertilizer for improving the $P$ status and growth of plants in alkaline soils (Wahid et al., 2019).

Table 4. $P$ value from ANOVA test on soil biological characteristic $(\alpha=0.05)$

\begin{tabular}{ccccc}
\hline Treatment & Root infection & Spore density $100 \mathrm{~g}^{-1}$ of soil & Easily extracted Glomalin & Total Glomalin \\
\hline Mycorrhizae (M) & $<0.01^{* *}$ & $<0.01^{* *}$ & $<0.01^{* *}$ & $<0.01^{* *}$ \\
Soil Ameliorant (S) & $<0.01^{* *}$ & $<0.01^{* *}$ & $<0.01^{* *}$ & $<0.01^{* *}$ \\
$\mathrm{M} * \mathrm{~S}$ & $<0.01^{* *}$ & $<0.01^{* *}$ & $<0.01^{*}$ & $<0.01^{* *}$ \\
\hline
\end{tabular}

Remarks: $^{*}=$ significant difference; ${ }^{* *}=$ highly significant difference

Table 5. Effect of mycorrhizae and soil ameliorant on soil biological properties

\begin{tabular}{cccccc}
\hline \multicolumn{2}{c}{ Treatment } & $\begin{array}{c}\text { Root infection } \\
(\%)\end{array}$ & Spore density $100 \mathrm{~g}^{-1}$ of soil & EEG $\left(\mathrm{mg} \mathrm{g}^{-1}\right)$ & TG $\left(\mathrm{mg} \mathrm{g}^{-1}\right)$ \\
\hline & S0 & $0 \pm 0.00 \mathrm{~g}$ & $0 \pm 0.00 \mathrm{f}$ & $0.067 \pm 0.06 \mathrm{cde}$ & $0.094 \pm 0.03 \mathrm{bc}$ \\
M0 & S1 & $0 \pm 0.00 \mathrm{~g}$ & $0 \pm 0.00 \mathrm{f}$ & $0.138 \pm 0.00 \mathrm{~cd}$ & $0.299 \pm 0.05 \mathrm{a}$ \\
& S2 & $0 \pm 0.00 \mathrm{~g}$ & $0 \pm 0.00 \mathrm{f}$ & $0.038 \pm 0.01 \mathrm{e}$ & $0.044 \pm 0.01 \mathrm{c}$ \\
& S3 & $0 \pm 0.00 \mathrm{~g}$ & $0 \pm 0.00 \mathrm{f}$ & $0.056 \pm 0.09 \mathrm{de}$ & $0.192 \pm 0.03 \mathrm{abc}$ \\
& S4 & $0 \pm 0.00 \mathrm{~g}$ & $0 \pm 0.00 \mathrm{f}$ & $0.164 \pm 0.04 \mathrm{bc}$ & $0.176 \pm 0.05 \mathrm{abc}$ \\
& S5 & $0 \pm 0.00 \mathrm{~g}$ & $0 \pm 0.00 \mathrm{f}$ & $0.070 \pm 0.05 \mathrm{cde}$ & $0.09 \pm 0.02 \mathrm{bc}$ \\
& S6 & $0 \pm 0.00 \mathrm{~g}$ & $0 \pm 0.00 \mathrm{f}$ & $0.096 \pm 0.01 \mathrm{cde}$ & $0.100 \pm 0.01 \mathrm{bc}$ \\
\hline & S0 & $98.33 \pm 1.53 \mathrm{a}$ & $54 \pm 2.00 \mathrm{a}$ & $0.099 \pm 0.07 \mathrm{cde}$ & $0.300 \pm 0.03 \mathrm{a}$ \\
& S1 & $80.00 \pm 1.00 \mathrm{~d}$ & $28 \pm 2.00 \mathrm{~d}$ & $0.290 \pm 0.09 \mathrm{a}$ & $0.300 \pm 0.01 \mathrm{a}$ \\
& S2 & $85.00 \pm 3.00 \mathrm{c}$ & $36 \pm 2.00 \mathrm{c}$ & $0.073 \pm 0.03 \mathrm{cde}$ & $0.298 \pm 0.01 \mathrm{a}$ \\
& S3 & $70.00 \pm 3.00 \mathrm{f}$ & $20 \pm 2.00 \mathrm{e}$ & $0.074 \pm 0.00 \mathrm{cde}$ & $0.088 \pm 0.01 \mathrm{c}$ \\
& S4 & $98.00 \pm 2.65 \mathrm{a}$ & $28 \pm 2.00 \mathrm{~d}$ & $0.243 \pm 0.04 \mathrm{ab}$ & $0.269 \pm 0.05 \mathrm{ab}$ \\
& S5 & $90.00 \pm 2.00 \mathrm{~b}$ & $44 \pm 4.00 \mathrm{~b}$ & $0.113 \pm 0.11 \mathrm{cde}$ & $0.189 \pm 0.06 \mathrm{abc}$ \\
& S6 & $75.00 \pm 1.00 \mathrm{e}$ & $30 \pm 4.00 \mathrm{~d}$ & $0.107 \pm 0.08 \mathrm{cde}$ & $0.178 \pm 0.01 \mathrm{abc}$ \\
\hline
\end{tabular}

Remarks: The numbers after the \pm sign are standard deviation, the numbers followed by the same letters indicate no difference according to Tukey HSD ( $\alpha=0.05)$; TG= Total Glomalin; EEG= Easily extracted Glomalin; $\mathrm{M0}=$ without mycorrhizae; M1= mycorrhizae 6 spores/plant; S0= without ameliorant; S1= cow dung 60 tons ha- ${ }^{-1}, \mathrm{~S} 2=$ rock phosphate $150 \mathrm{~kg} \mathrm{ha}^{-1}$; $\mathrm{S} 3=$ biochar 25 tons ha-1; S4= cow dung 60 tons ha-1 + rock phosphate $150 \mathrm{~kg} \mathrm{ha}^{-1}$; S5= cow dung 60 tons ha-1 + biochar 25 tons ha-1; $\mathrm{S} 6=$ rock phosphate $150 \mathrm{~kg} \mathrm{ha}^{-1}+$ biochar 25 tons ha-1. 
Table 6. Correlation $(r)$ analysis of soil characteristics

\begin{tabular}{lccccc}
\hline \multicolumn{1}{c}{ Soil Characteristics } & Available P & CEC & Root Infection & Spore Density & Total Glomalin \\
\hline Soil Organic Carbon & 0.112 & 0.221 & & & \\
Root infection & $\mathbf{0 . 3 6 4 ^ { * }}$ & $\mathbf{0 . 3 7 8 ^ { * }}$ & & & \\
Spore density & $\mathbf{0 . 3 6 3 ^ { * }}$ & $\mathbf{0 . 3 0 7 ^ { * }}$ & $\mathbf{0 . 9 4 6 * *}$ & & \\
Total Glomalin & $\mathbf{0 . 3 1 \mathbf { 8 } ^ { * }}$ & 0.050 & $\mathbf{0 . 4 8 5 ^ { * * }}$ & $\mathbf{0 . 4 9 0 ^ { * * }}$ & \\
Easily Extracted Glomalin & $-\mathbf{0 . 4 1 1 ^ { * * }}$ & 0.233 & $\mathbf{0 . 3 7 8 ^ { * }}$ & 0.239 & $\mathbf{0 . 4 7 6 ^ { * * }}$ \\
\hline
\end{tabular}

Remarks: *=significant at $\alpha=0.05 ; * *=$ significant at $\alpha=0.01$

The application of cow dung and biochar had a significant effect on increasing SOC, P availability, and CEC (Haliru et al., 2018). This is in line with Alvernia et al. (2017), who observed an increase in SOC by $26 \%$ after the application of cow dung of 5 tons ha ${ }^{-1}$ on Alfisols. The addition of biochar to sandy soil will increase the concentration of humic and fluvic acids, followed by an increase in SOC (Amoakwah et al., 2020; Głąb et al., 2020), and increased available $P$ averages of $7.9 \%$ in paddy soil (Jing et al., 2020). The interaction of organic matter and biochar may work in both directions because the addition of easily degradable substrates or the presence of labile SOM in biochar-amended soils can increase biochar decomposition (Ameloot et al., 2013). Application of cow dung and biochar can provide the highest organic $C$ in sandy soil.

TG and EEG with mycorrhizae and cow dung increased $213 \%$ and $333 \%$, respectively, compared to those without mycorrhizae and soil ameliorants (Table 5). Wu et al. (2014) reported that root colonization significantly positively correlated with EEG, difficultly-extractable GRSP (DE-GRSP), and TG. In more detail, Wu et al. (2015) said that GRSP concentrations are often positively related to root colonization and soil hyphae. Greater root systems could provide more chances to be colonized by AMF, thereby increasing the production of hyphae, spore density and more GRSP production. The external root of mycorrhizae produces compounds in the form of glomalin glycoproteins and organic acids that can increase SOC (Syamsiyah et al., 2014). Adding cow dung and biochar with high carbon will increase nutrients and soil biological activity. Mycorrhizae are obligate biotrophs that depend on host cells for their C supply, up to $85 \%$ of the carbon is transferred to the mycorrhizae and then used to form glomalin (Vlček \& Pohanka, 2020). Mycorrhizae will produce a protein, glomalin, which is called GRSP, and increase production of glomalin due to increasing atmospheric $\mathrm{CO}_{2}$ because of the symbiotic association that exists between plants and mycorrhizae (Singh et al., 2013).

The increasing doses of biochar can increase enzyme activities and improve soil microbial biomass, thus suggesting a selection pressure of biochar to microbial population in soil (Kocsis et al., 2020). According to Xie et al. (2015), giving cow dung can increase levels of EEG, and TG due to increased nutrients for soil biological activity will be followed by the release of growth-promoting substances. Glomalin is a component resulting from mycorrhizal symbiotic activity with root plants. This substance is a constituent of the walls of hyphae and spores produced by mycorrhizae during nutrient and water transport activities. After the activity of the hyphae stops, glomalin will be released with the hyphae and unite with minerals in the soil. Even though glomalin from the soil is difficult to extract, mycorrhizae inoculation could extract it and then increase the concentration of EEG. This is in line with Syamsiyah et al. (2014), who found that there was a significant difference effect between no inoculation and mycorrhizae inoculation with EEG and TG. Increasing the TG was followed by root infection and spores that were produced by mycorrhizae (Birhane et al., 2020). The evidence is the very strong correlation between the root infection and the spore density $(r=0.946, P<0.01)$ and TG $(r=0.485, P<$ $0.01)$ and EEG $(r=0.378, P<0.05)$ (Table 6$)$.

Application of mycorrhizae and cow dung-biochar significantly increased CEC up to $216 \%$ and available $P$ up to $675 \%$ compared to those without mycorrhizae (control) (Table 3). There was positive correlation between CEC and root infection $(r=0.378, P<0.05)$ and spore density $(r=0.307$, $P<0.05$ ) (Table 6). This is because mycorrhizae play an active role in the process of organic $C$ decomposition, releasing organic acids to increase soil CEC and the availability of $P$ (Syibli et al., 2013). Leaching of soil nutrients was not easy to occur because of the wider absorption area due to the high content of soil organic colloids (Bruun et al., 2012). The high soil organic matter content will be followed by an increase in nutrient absorption due to the CEC value (Sithole \& Magwaza, 2019). Maftu'ah \& Nursyamsi (2019) reported that biochar application correlated positively with $\mathrm{P}$ availability and increased $P$ uptake in maize plants compared to control treatment. The increase in $\mathrm{P}$ availability is in line with the increase in root infection and spore density. This is evidenced by the positive correlation between $\mathrm{P}$ availability with root infection $(r=0.364, P<0.05)$, spore density $(r=0.363, P<$ 0.05), TG $(r=0.318, P<0.05)$ (Table 6).

The application of mycorrhizae and rock phosphate can increase the availability of phosphorus in the soil. Mycorrhizae of six spores/plant and rock phosphate $150 \mathrm{~kg}$ $\mathrm{ha}^{-1}$ showed the highest available $P$-value, $115.17 \mathrm{ppm}$, an increase of $1,053 \%$ compared to control (Table 3). Mycorrhizae inoculation can accelerate mycorrhizae colonization of plant roots when added with rock phosphate as a source of phosphorus. Mycorrhizae inoculation combines with rock phosphate to increase soil $P$ availability and accelerate the solubility of $P$ through organic acids released (Li et al., 2019; Sosa-Hernández et al., 2019).

The combination of cow dung 60 tons ha ${ }^{-1}$ and rock phosphate $150 \mathrm{~kg} \mathrm{ha}^{-1}$ increased base cations in the soil. During the decomposition process of organic matter, nutrients are released, including base cations (Cai et al., 2019). In addition, rock phosphate also contains elements of $\mathrm{Ca}$ and Mg (Kasno \& Sutriadi, 2012); when P elements are released, $\mathrm{Ca}$ and $\mathrm{Mg}$ elements are also released. An increase in the elements of $\mathrm{Ca}$ and $\mathrm{Mg}$ will be followed by a decrease in $\mathrm{Na}$, evidenced by the decreasing ESP value. The application 
of mycorrhizae and cow dung-biochar significantly reduced the ESP value by a decrease of $66 \%$ compared to the control (Table 3). This is in line with the finding of (Rahayu, Syamsiyah, et al., 2019), that biochar and compost can reduce soil salinity levels. Mycorrhizae play an important role in reducing the stress of their host plants in stressful environments, including high levels of soil salinity (Barin et al., 2013). A high concentration of the Na element will affect the salinity of the soil, disruption of growth, and decrease productivity in plants. In addition, plants with $\mathrm{Na}$ toxicity can reduce N-P-K uptake (Yun et al., 2018) and increasing $\mathrm{Na}^{+}, \mathrm{Cl}^{-}$ and $\mathrm{SO}_{4}{ }^{2-}$ causes ion imbalance in plants (Syamsiyah et al., 2020).

In this study, mycorrhizae six spores/plant and cow dung 60 tons ha ${ }^{-1}$-biochar 25 tons ha ${ }^{-1}$ (M1S5) affected to increase of CEC and decrease of ESP, and mycorrhizae-rock phosphate increased available $\mathrm{P}$ (Table 3); application of only mycorrhizae increased root infection, spore density and TG, but mycorrhizae with cow dung was the best for EEG (Table 5). The lowest SOC was in non-mycorrhizae and rock phosphate; available $\mathrm{P}, \mathrm{CEC}$, root infection, and spore density were found in the control (Tables 3 and Table 5), but the lowest of TG and EEG were found in non-mycorrhizae-rock phosphate (MOS2) (Table 5).

\section{Conclusion}

Addition of mycorrhizae up to six spores/plant, cow dung and biochar was the best ameliorant combination for improving soil chemical and biological characteristics in sandy soil. Application of mycorrhizae six spores/plant and cow dung 60 tons ha ${ }^{-1}$-biochar 25 tons ha $^{-1}$ increased SOC (235\%), available P (675\%), CEC (216\%), TG (101\%), EEG (69\%) and decreased ESP (66\%). It also increased root infection and spore density than control (without mycorrhizae and soil ameliorants). The lowest of SOC, TG and EEG were found in non-mycorrhizae-rock phosphate (MOS2); but available $P$, $\mathrm{CEC}$, root infection, spore density were found in the control. Further research is required regarding the long-term effects of soil ameliorants on sandy soil.

\section{Acknowledgements}

The authors would like to express their gratitude to Universitas Sebelas Maret for facilitating this research through the scheme of Priority Research Grant of Non APBN 2021 with the Letter of Agreement Number: 260/UN27.22/HK.07.00/2021.

\section{Declaration of Competing Interest}

The authors declare no competing financial or personal interests that may appear and influence the work reported in this paper.

\section{References}

Alvernia, P., Minardi, S., \& Suntoro. (2017). Zeolite and Organic Fertilizer Application to The Improvement of Available $P$ and Soybean (Glycine max L) Seed Yield in Alfisols. Sains Tanah - Journal of Soil Science and Agroclimatology, 14(2), 83-89. https://doi.org/10.15608/stjssa.v14i2.839
Ameloot, N., Graber, E. R., Verheijen, F. G. A., \& De Neve, S. (2013). Interactions between biochar stability and soil organisms: review and research needs. European Journal of Soil Science, 64(4), 379-390. https://doi.org/10.1111/ejss.12064

Amoakwah, E., Arthur, E., Frimpong, K. A., Parikh, S. J., \& Islam, R. (2020). Soil organic carbon storage and quality are impacted by corn cob biochar application on a tropical sandy loam. Journal of Soils and Sediments, 20(4), 1960-1969. https://doi.org/10.1007/s11368-019-02547-5

Barin, M., Aliasgharzad, N., Olsson, P. A., Rasouli-Sadaghiani, M., \& Moghddam, M. (2013). Abundance of arbuscular mycorrhizal fungi in relation to soil salinity around Lake Urmia in northern Iran analyzed by use of lipid biomarkers and microscopy. Pedobiologia, 56(4), 225232.

https://doi.org/https://doi.org/10.1016/j.pedobi.201 3.09.001

Birhane, E., Gebretsadik, K. F., Taye, G., Aynekulu, E., Rannestad, M. M., \& Norgrove, L. (2020). Effects of Forest Composition and Disturbance on Arbuscular Mycorrhizae Spore Density, Arbuscular Mycorrhizae Root Colonization and Soil Carbon Stocks in a Dry Afromontane Forest in Northern Ethiopia. Diversity, 12(4), 1-16. https://doi.org/10.3390/D12040133

Bruun, E. W., Petersen, C., Strobel, B. W., \& HauggaardNielsen, H. (2012). Nitrogen and Carbon Leaching in Repacked Sandy Soil with Added Fine Particulate Biochar. Soil Science Society of America Journal, 76(4), 1142-1148. https://doi.org/10.2136/sssaj2011.0101

Cai, A., Xu, M., Wang, B., Zhang, W., Liang, G., Hou, E., \& Luo, Y. (2019). Manure acts as a better fertilizer for increasing crop yields than synthetic fertilizer does by improving soil fertility. Soil and Tillage Research, 189, 168-175. https://doi.org/10.1016/j.still.2018.12.022

de Amaral Leite, A., de Souza Cardoso, A. A., de Almeida Leite, R., de Oliveira-Longatti, S. M., Filho, J. F. L., de Souza Moreira, F. M., \& Melo, L. C. A. (2020). Selected bacterial strains enhance phosphorus availability from biochar-based rock phosphate fertilizer. Annals of Microbiology, 70(1), 1-13. https://doi.org/10.1186/s13213-020-01550-3

Głąb, T., Żabiński, A., Sadowska, U., Gondek, K., Kopeć, M., Mierzwa-Hersztek, M., Tabor, S., \& Stanek-Tarkowska, J. (2020). Fertilization effects of compost produced from maize, sewage sludge and biochar on soil water retention and chemical properties. Soil and Tillage Research, 197, 1-10. https://doi.org/10.1016/j.still.2019.104493

Haliru, M., Dikko, A., Audu, M., \& Aliyu, I. (2018). Effect of cow dung on soil properties and performance of sweet potato (Ipomoea batatas L.) in Sudan Savanna, Nigeria. International Journal of Plant \& Soil Science, 212-216. https://doi.org/10.9734/ijpss/2015/14471

Han, S. H., An, J. Y., Hwang, J., Kim, S. B., \& Park, B. B. (2016). The effects of organic manure and chemical fertilizer on the growth and nutrient concentrations of yellow poplar (Liriodendron tulipifera Lin.) in a nursery 
system. Forest Science and Technology, 12(3), 137-143. https://doi.org/10.1080/21580103.2015.1135827

Huang, J., \& Hartemink, A. E. (2020). Soil and environmental issues in sandy soils. Earth-Science Reviews, 208, 1-22. https://doi.org/10.1016/j.earscirev.2020.103295

Jing, Y., Zhang, Y., Han, I., Wang, P., Mei, Q., \& Huang, Y. (2020). Effects of different straw biochars on soil organic carbon, nitrogen, available phosphorus, and enzyme activity in paddy soil. Scientific Reports, 10(1), 1-12. https://doi.org/10.1038/s41598-020-65796-2

Kasno, A., \& Sutriadi, M. T. (2012). Indonesian RockPhosphate Effectivity for Maize Crop on Ultisols Soils. AGRIVITA, Journal of Agricultural Science, 34(1), 14-21. https://doi.org/10.17503/agrivita.v34i1.134

Kocsis, T., Kotroczó, Z., Kardos, L., \& Biró, B. (2020). Optimization of increasing biochar doses with soilplant-microbial functioning and nutrient uptake of maize. Environmental Technology \& Innovation, 20, 101191. https://doi.org/10.1016/j.eti.2020.101191

Li, Y., Wang, S., Lu, M., Zhang, Z., Chen, M., Li, S., \& Cao, R. (2019). Rhizosphere interactions between earthworms and arbuscular mycorrhizal fungi increase nutrient availability and plant growth in the desertification soils. Soil and Tillage Research, 186, 146-151. https://doi.org/10.1016/j.still.2018.10.016

Liu, M., Zhao, Z., Chen, L., Wang, L., Ji, L., \& Xiao, Y. (2020). Influences of arbuscular mycorrhizae, phosphorus fertiliser and biochar on alfalfa growth, nutrient status and cadmium uptake. Ecotoxicology and Environmental Safety, 196, 1-8. https://doi.org/10.1016/j.ecoenv.2020.110537

Maftu'ah, E., \& Nursyamsi, D. (2019). Effect of Biochar on Peat Soil Fertility and NPK Uptake by Corn [biochar; corn; NPK uptake; peatland; soil fertility]. 2019, 41(1), 64-73. https://doi.org/10.17503/agrivita.v41i1.854

Minardi, S., Haniati, I. L., \& Nastiti, A. H. L. (2020). Adding manure and zeolite to improve soil chemical properties and increase soybean yield [Cow manure; Seed weight; Soybeans; Organic fertilizers; Zeolite]. 2020, 17(1),

1-6. https://doi.org/10.20961/stjssa.v17i1.41087

Prasetyo, R. (2014). Pemanfaatan Berbagai Sumber Pupuk Kandang sebagai Sumber $\mathrm{N}$ dalam Budidaya Cabai Merah (Capsicum annum L.) di Tanah Berpasir. Planta Tropika: Journal of Agro Science, 2(2), 125-132. https://doi.org/10.18196/pt.2014.032.125-132

Putra, S. S., Putra, E. T. S., \& Widada, J. (2020). The Effects of Types of Manure and Mycorrhizal Applications on Sandy Soils on the Growth and Yield of Curly Red Chili (Capsicum annum L.). Caraka Tani: Journal of Sustainable Agriculture, 35(2), 258-267. https://doi.org/10.20961/carakatani.v35i2.34971

Rahayu, Saidi, D., \& Herlambang, S. (2019). Pengaruh biochar tempurung kelapa dan pupuk kandang pada tanah pasir pantai. Jurnal Tanah Dan Air, 16(2), 10. https://doi.org/10.31315/jta.v16i2.3985

Rahayu, Syamsiyah, J., Cahyani, V. R., \& Fauziah, S. K. (2019). The Effects of Biochar and Compost on Different Cultivars of Shallots (Allium ascalonicum L.) Growth and Nutrient Uptake in Sandy Soil Under Saline Water. Sains Tanah - Journal of Soil Science and Agroclimatology, 16(2), 216-228. https://doi.org/10.20961/stjssa.v16i2.34209

Raklami, A., Bechtaoui, N., Tahiri, A.-i., Anli, M., Meddich, A., \& Oufdou, K. (2019). Use of Rhizobacteria and Mycorrhizae Consortium in the Open Field as a Strategy for Improving Crop Nutrition, Productivity and Soil Fertility [Original Research]. Frontiers in Microbiology, 10(1106), 1-11. https://doi.org/10.3389/fmicb.2019.01106

Ramos, F. T., Dores, E. F. d. C., Weber, O. L. d. S., Beber, D. C., Campelo Jr, J. H., \& Maia, J. C. d. S. (2018). Soil organic matter doubles the cation exchange capacity of tropical soil under no-till farming in Brazil. Journal of the Science of Food and Agriculture, 98(9), 3595-3602. https://doi.org/10.1002/jsfa.8881

Richardson, A. E., \& Simpson, R. J. (2011). Soil Microorganisms Mediating Phosphorus Availability Update on Microbial Phosphorus. Plant Physiology, 156(3), 989996. https://doi.org/10.1104/pp.111.175448

Singh, P. K., Singh, M., \& Tripathi, B. N. (2013). Glomalin: an arbuscular mycorrhizal fungal soil protein. Protoplasma, 250(3), 663-669. https://doi.org/10.1007/s00709-012-0453-z

Sithole, N. J., \& Magwaza, L. S. (2019). Long-term changes of soil chemical characteristics and maize yield in no-till conservation agriculture in a semi-arid environment of South Africa. Soil and Tillage Research, 194, 1-9. https://doi.org/10.1016/j.still.2019.104317

Solly, E. F., Weber, V., Zimmermann, S., Walthert, L., Hagedorn, F., \& Schmidt, M. W. I. (2019). Is the content and potential preservation of soil organic carbon reflected by cation exchange capacity? A case study in Swiss forest soils. Biogeosciences Discuss., 2019, 1-32. https://doi.org/10.5194/bg-2019-33

Sosa-Hernández, M. A., Leifheit, E. F., Ingraffia, R., \& Rillig, M. C. (2019). Subsoil Arbuscular Mycorrhizal Fungi for Sustainability and Climate-Smart Agriculture: A Solution Right Under Our Feet? [Review]. Frontiers in Microbiology, 10(4), 1-12. https://doi.org/10.3389/fmicb.2019.00744

Syamsiyah, J., Herawati, A., \& Binafsihi, W. (2020). Study of levels water salinity on the growth of varieties of shallots (Allium ascalonicum L) in Alfisols. IOP Conference Series: Earth and Environmental Science, 423(1), 1-6. https://doi.org/10.1088/17551315/423/1/012065

Syamsiyah, J., Sunarminto, B. H., Hanudin, E., \& Widada, J. (2014). Pengaruh Inokulasi Jamur Mikoriza Arbuskula terhadap Glomalin, Pertumbuhan dan Hasil Padi [Glomalin; Mycorrhizae; nutrient uptake; rice yield]. Sains Tanah-Journal of Soil Science and Agroclimatoloy, 11(1). https://doi.org/10.15608/stjssa.v11i1.214

Syibli, M. A., Muhibuddin, A., \& Djauhari, S. (2013). Arbuscular mycorrhiza fungi as an indicator of soil fertility. AGRIVITA, Journal of Agricultural Science, 35(1), 10. https://doi.org/10.17503/agrivita.v35i1.228 
Vlček, V., \& Pohanka, M. (2020). Glomalin-an interesting protein part of the soil organic matter. Soil and Water Research, 15(2), 67-74. https://doi.org/10.17221/29/2019-SWR

Wahid, F., Sharif, M., Fahad, S., Adnan, M., Khan, I. A., Aksoy, E., Ali, A., Sultan, T., Alam, M., Saeed, M., Ullah, H., Basir, A., Noor, M., \& Khan, N. A. (2019). Arbuscular mycorrhizal fungi improve the growth and phosphorus uptake of mung bean plants fertilized with composted rock phosphate fed dung in alkaline soil environment. Journal of Plant Nutrition, 42(15), 1760-1769. https://doi.org/10.1080/01904167.2019.1643371

Wu, Q.-S., Cao, M.-Q., Zou, Y.-N., \& He, X.-h. (2014). Direct and indirect effects of glomalin, mycorrhizal hyphae and roots on aggregate stability in rhizosphere of trifoliate orange. Scientific Reports, 4(1), 5823. https://doi.org/10.1038/srep05823

Wu, Q.-S., Li, Y., Zou, Y.-N., \& He, X.-H. (2015). Arbuscular mycorrhiza mediates glomalin-related soil protein production and soil enzyme activities in the rhizosphere of trifoliate orange grown under different P levels. Mycorrhiza, 25(2), 121-130. https://doi.org/10.1007/s00572-014-0594-3

Xiao, Y., Liu, M., Chen, L., Ji, L., Zhao, Z., Wang, L., Wei, L., \& Zhang, Y. (2020). Growth and elemental uptake of Trifolium repens in response to biochar addition, arbuscular mycorrhizal fungi and phosphorus fertilizer applications in low-Cd-polluted soils. Environmental Pollution, 260,

https://doi.org/10.1016/j.envpol.2019.113761
Xie, H., Li, J., Zhang, B., Wang, L., Wang, J., He, H., \& Zhang, X. (2015). Long-term manure amendments reduced soil aggregate stability via redistribution of the glomalinrelated soil protein in macroaggregates. Scientific Reports, 5(1), 1-9. https://doi.org/10.1038/srep14687

Yost, J. L., \& Hartemink, A. E. (2019). Chapter Four - Soil organic carbon in sandy soils: A review. In D. L. Sparks (Ed.), Advances in Agronomy (1st ed., Vol. 158, pp. 217-310). Academic Press. https://doi.org/10.1016/bs.agron.2019.07.004

Yun, P., Xu, L., Wang, S.-S., Shabala, L., Shabala, S., \& Zhang, W.-Y. (2018). Piriformospora indica improves salinity stress tolerance in Zea mays L. plants by regulating $\mathrm{Na}+$ and $\mathrm{K}+$ loading in root and allocating $\mathrm{K}+$ in shoot. Plant Growth Regulation, 86(2), 323-331. https://doi.org/10.1007/s10725-018-0431-3

Zhang, M., Cheng, G., Feng, H., Sun, B., Zhao, Y., Chen, H., Chen, J., Dyck, M., Wang, X., Zhang, J., \& Zhang, A. (2017). Effects of straw and biochar amendments on aggregate stability, soil organic carbon, and enzyme activities in the Loess Plateau, China. Environmental Science and Pollution Research, 24(11), 10108-10120. https://doi.org/10.1007/s11356-017-8505-8

Zulkoni, A., Rahyuni, D., \& Nasirudin, N. (2020). Pengaruh Bahan Organik Dan Jamur Mikoriza Arbuskula Terhadap Harkat Tanah Pasir Pantai Selatan Yogyakarta Yang Menjadi Medium Pertumbuhan Jagung (Zea Mays). Media Ilmiah Teknik Lingkungan (MITL), 5(1), 8-15. https://doi.org/10.33084/mitl.v5i1.1348 